\title{
FINANCING CONSTRAINTS AND CORPORATE INVESTMENT: RESPONSE TO KAPLAN AND ZINGALES
}

\author{
Steven M. Fazzari, R. Glenn Hubbard, and Bruce C. Petersen*
}

January 1996

-Fazzari: Washington University and the Jerome Levy Economics Institute: Hubbard: Columbia University and the National Bureau of Economic Research; Petersen: Washington University. We are grateful to Charles Calomiris, Robert Carpenter, Mark Gertler. Simon Gilchrist, Kevin Hassett, Charles Himmelberg, and Anil Kashyap for comments and suggestions. 


\section{INTRODUCTION}

In a (1988) paper. entitled "Financing Constraints and Corporate Investment" (hereafter. FHP), we use models of asymmetric information in capital markets to motivate links between internal funds and investment, holding constant investment opportunities. We interpret the results of our tests as consistent with the presence of economically important financing constraints on the investment of some firms. Since the publication of FHP, a large empirical literature has explored internal funds models of firm-level investment (see, e.g., the review in Hubbard, 1995). This literature, for the most part, supports both the findings and interpretation offered in FHP.

Kaplan and Zingales (1995, hereafter "KZ") argue that when they examine in greater detail some of the firms studied by FHP, the data do not support the presence of financing constraints. Further, $\mathrm{KZ}$ use this apparent contradiction of the FHP results to criticize much of the literature on internal funds models of investment and their applications to business decisionmaking and public policy. In this response, we show that most of the concerns raised by $\mathrm{KZ}$ have been addressed by studies after FHP. This additional research corroborates the FHP findings in almost every case. $\mathrm{KZ}$ consider very little of this work. We also argue that $\mathrm{KZ} ; \mathrm{s}$ interpretation of their primary findings is incorrect, in large part because of their operational definition of financing constraints as well as problems with the way they classify firms into financially constrained and unconstrained groups.

The first of KZ's main findings is that (p. 2) "in 85 percent of firm-years, the firms could have increased their investment," fïnanced by either unused lines of credit or cash stocks. KZ conclude from this observation that these firms are not financially constrained. 
Their operational definition of the absence of financing constraints is the ability of a firm to invest more at a particular moment in time. We, and probably most other economists who do research on financing constraints. do not agree with this operational definition. It ignores firms incentives to maintain debt capacity and precautionary cash stocks that can be used to partially offest shocks to the flow of internal finance. We therefore do not believe that $\mathrm{KZ}$ support their conclusion that a large proportion of the the ample they study is not finanically constrained.

The second main result in $\mathrm{KZ}$ is that when they split the t9 low-dividend firms from the FHP sample into five subgroups, the group that they clam is ks financially constrained exhibits (p. 2) "a significantly greater investment-cash tlow sensitivity than those firms classificd as more financially constrained." They argue that this result casts doubt on the FHP interpretation that these low-dividend firms are financially constrained. For several reasons, these findings are not inconsistent with the conclusions of FHP. First, it is difficult to distinguish so finely the degree of financing constraints. especially in such a small sample. The operational classification criteria employed in the $\mathrm{KZ}$ method anc also misleading. As we have already mentioned. high cash stocks may indicate the presence rather than the absence of constraints in a dynamic context where financially constrained firms use cash stocks to buffer their insestment against expected future financial restrictions. Furthermore, low levels of debt. Which $\mathrm{KZ}$ associate with the absence of constraints, maty simply indicate severe moral hazard and adverse selection problems that create binding constraints.

In our view. $\mathrm{KZ}$ do not identify different degrees of tinancial constraints across the subgroups in their regressions. Rather. we argue that the FHP firm-years KZ classify as most 
financially constrained are actually observations from years when firms are financially distressed. (The criteria for inclusion in their most constrained group include the violation of debt covenants and renegotiation of debt payments.) $\mathrm{KZ}$ themselves note that financially distressed firms may be restricted by creditors from using cash flow for investment and might therefore have a relatively low investment response to changes in cash flow. At the same time. the growth opportunities available to healthy firms (which $\mathrm{KZ}$ classify as unconstrained) may exhaust their low-cost internal funds and make their investment relatively more sensitive to cash flow if they must pay a premium for external funds. As a result, we disagree with $\mathrm{KZ}:$ conclusion that the pattern of their regression results is inconsistent with the findings presented in FHP.

In addition. because the FHP sample that $\mathrm{KZ}$ study was designed to exclude financially distressed firms, very few observations fall into the categories $\mathrm{KZ}$ label as constrained. As a result. the sample does not contain adequate heterogeneity to identify meaningful differences across their regression samples. The vast majority of observations in their constrained-firm regressions ( 84 percent) are from periods that their method identifies as unconstrained. The $\mathrm{KZ}$ regression results simply do not provide credible information about how firm behavior differs, even across their own financing constraint classifications.

Our response is organized as follow's. Section II briefly summarizes the logic of the original FHP test. Section III reveals the significant extent to which the conceptual criticisms raised by $\mathrm{KZ}$ have been addressed in previous research, with results broadly supportive of the FHP lindings. The main thrust of our reply appears in section IV, which criticizes the approach $\mathrm{KZ}$ use to elassify the $49 \mathrm{FHP}$ firms into their five subgroups. In Section V, we 
explore potential econometric problems with the $\mathrm{KZ}$ approach. The variables they use have measurement problems, including distortions introduced by the use of hook values of capital and assets rather than replacement values. Moreover. because gross investment cannot fall below zero. a censored regression bias could cause misleading results for financially distresied firms. Section VI concludes.

\section{THE CORRELATION BETWEEN INVESTMENT AND LIQUIDITY}

The essence of the FHP test is as follows. If captal-matret imperfections cause firms to face hinding financial constraints. proxies for internal funds or liquidity may affect firms' investment. holding constant investment opportunities. In FHP. we used the $Q$ model of investment as a benchmark because it relies on $Q$ as a summary vattutic for investment opportunities. Under certain assumptions (see. e.g. Hayashi. 1982). the basic $Q$ model can be expressed as follows:

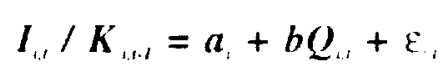

where $i$ denotes the firm and the time period. respectively: $I$ and $K$ represent investment and the capital stock. respectively: $Q$ is the tax-adjusted value of Tobin' y: as a firm-specific constant representing the long-run normal value of the investment-capital ratio: and $\varepsilon$ is an

'B! "binding financing constraints." we mean conditions that raise the cost of external finance (debt or equity) above the opportunity cost of internal finance. In the extreme. this condition is associated with credit and/or equity rationing lece Hubbard. 1995, section 2 for further discussion). 
optimization error. The value of the coefficient $b$ is inversely related to the marginal cost of adjusting the capital stock.

In the absence of asymmetric information between firm insiders and external capital markets. all available information to guide the firm's investment decision is summarized in $Q$. In particular. the magnitude of internal funds known to the market should have no incremental explanatory power beyond $Q$. In FHP, we used firm cash flow $(C F)$ as a measure of internal funds and estimated:

$$
I_{u} / K_{4+1}=a_{1}+b Q_{u}+c\left(C F_{4,} / K_{u,-1}\right)+\varepsilon_{u}
$$

Absent capital-market frictions, the estimated coefficient $c$ should be zero as long as $Q$ controls adequately for investment opportunities; a significantly positive value of $c$ corresponds to a rejection of the frictionless model and suggests the presence of financing constraints.

Because of potential problems associated with measuring $Q$, we carried the approach a step further. Models of information and incentive problems suggest that firms are likely to differ in the extent to which financial factors affect their investment. We examined heterogeneity in the effect of cash flow on investment to determine if groups of firms that were most likely to face financing constraints had higher estimated $c$ coefficients.

Though many a priori groupings of firms are plausible (see the review in Hubbard, 1995), we used dividend-payout ratios to classify firms. In particular, to identify firms that are most likely to face binding financing constraints, we extended a model from the public 
finance literature. Suppose that the cost of adjusting the capital stock is high relative to the cost of adjusting dividend payout. Then, if the cost of external funds exceeds that of internal funds (because of, e.g., tax factors, transactions costs, or information costs), paying substantial dividends in the presence of promising investment opportunities would not be consistent with value maximization. Therefore, if financing constraints are important. the investment of firms with good investment opportunities that retain all or nearly all of their earnings will likely be more sensitive to cash flow than that for high-payout firms with a large (dividend) cushion of funds to finance investment.

We used panel data on 421 manufacturing firms over the period from 1970 to 1984 constructed from Value Line sources. To implement the firm classification by retention behavior, we grouped firms into three categories (in decreasing likelihood of being financeconstrained) -- high retention, medium retention, and low retention. We found significantly larger estimated cash flow coefficients $(c)$ for the high-retention firms than for the other groups. It is this cross-sectional difference that led us to conclude that financing constraints are likely to be important in many firms' investment decisions. The cross-sectional differences in cash flow effects on investment we found in the basic $Q$ model remained when sales or user cost of capital variables were introduced (as additional controls for investment opportunities) and when the data were further decomposed by two-digit S.I.C. industry groups. The basic FHP finding that a priori groupings of "constrained" and "unconstrained" firms have different determinants of investment. with internal funds being an important explanatory variable only for the former group, has been corroborated in studies of data for many countries outside the United States (see Hubbard. 1995: and Schiantarelli, 1995). 


\section{ISSUES RAISED IN FHP-STYLED TESTS}

While cross-sectional differences in the FHP results support an important role for information-related frictions in firms' financing and investment decisions, the tests suggest potential problems, which much research has addressed. These problems relate to: (1) the $a$ priori classification of firms. (2) the extent to which $Q$ is a good proxy for underlying investment opportunities. (3) whether the tests identify changes in internal funds independent of changes in investment opportunities, and (4) whether the observed link between cash flow and investment reflects non-value-maximizing behavior by managers as opposed to financing constraints. The large literature on these issues is reviewed in Hubbard (1995). ${ }^{2}$ Below we focus on these points. which correspond to those emphasized by $\mathrm{KZ}$.

\section{A. A Priori Classification of Firms}

The FHP tests emphasize cross-sectional differences in effects of internal funds on firms' investment. This emphasis raises two issues: whether different sample splits lead to consistent results, and whether any fixed grouping is reasonable.

Many other firm groupings have been studied in the literature. Hoshi, Kashyap, and Schartstein 11991 ) consider the significance of capital-market imperfections for Japanese firms. They use membership in a keiretsu, or large industrial group, as a sorting device. The

\footnotetext{
: Much of this literature is simply not referenced by $\mathrm{KZ}$, who argue on page 1 of their paper that "despite the size and policy relevance of this literature, the fundamental assumptions underlying it have been largely unexplored."
} 
idea is that keiretsu firms have access to external funds from the group "main bank," which monitors member firms closely. As a consequence. cash flow should have a smaller effect on investment. holding constant investment opportunities lats with FHP. measured by $Q$ ), for member firms than for firms not affiliated with keiretsu groups. While liquidity effects on investment are important for nongroup firms. they are much less impurtant for group firms. In another study, Whited (1992) splits a sample of Compustat manufacturing firms according 10 whether the firm had a bond rating at the beginning of the time period, the presample debt-assets ratio, and the pre-sample ratio of interest payments to cash flow. As proxies for "internal net worth." Whited uses the debt-issets ratu and the ratio of interest payments to cash flow. She finds that these financial vartables have larger effects on investment for the a priori constrained firms in cach of the sample plits.

Schaller (1993) suggests a number of groupings for firms. which he argues are based on exogenous firm characteristics and tied to problems of asymmeric information. Using panel data on Canadian firms. Schaller estimates variants of the FHP specification for: young versus mature firms (to capture likely differences in the cost of external equity finance), firms with dispersed cersus concentrated ownership (a proxy for potential agency costs), and firms which are members of industrial groups versus those which are noc following the approach of Hoshi. Kashyap, and Scharfstein. 1991). Consistent with the importance of informationclated capital-market imperfections. cash flow effects on investment holding constant $Q$ ) are more pronounced for young firms. firms with dispersed ownership. and non-group firms.

\footnotetext{
"Whited estimates the Euler equation for the chotce of the capital stock. This approach is discussed helow.
} 
The assumption that only a particular group of firms faces costly external finance is analytically and empirically convenient. Firms may, however, switch between "constrained" and "unconstrained" regimes depending upon shifts in investment opportunities and the availability of internal or external finance. Also, it is important to consider investment and financial policy jointly; firms may, for example, accumulate liquidity as a buffer against future constraints.

Gross (1994) models investment and financing decisions jointly, investigating timeseries as well as cross-sectional implications of financing constraints. In Gross's approach, tïrms manage investments in physical capital and liquid assets to mitigate bankruptcy risk, while availing themselves of the resources necessary to undertake investment projects. Working with a framework used in the "buffer stock" literature on consumption, Gross obtains results that support the intuition of the simple FHP model. When he estimates the optimal policy function for the firm's next-period capital stock as a function of current internal tunds, he finds it to be flat. That is, for firms with high net worth, neoclassical predictions obtain. When the firm becomes constrained due to lower internal funds, a significant fraction of each incremental dollar of internal funds is invested. Finally, when the firm is significantly constrained, because desired capital is very high relative to internal funds, the firm is willing to obtain external finance.

$\mathrm{KZ}$ ilaim to replace the various approaches used to classify firms into constrained and unconstrained groups with what they call "direct observation." We find this claim to be both misleading (because no direct observation of binding constraints is possible) and difficult to extend to other contexts (because it requires complex and subjective judgement). We expand 
on our criticisms of their approach in section IV. We agree with KZ. however. that it may be possible to obtain useful evidence by studying clearly defined. objective measures of costs of externall finance.

One such research program has been started by Calomiris and Himmelberg (1995), Who examine costs of firms' bringing public securities to market. Calomiris and Himmelberg argue that the expected underwriting costs of a seasoned equity issue te.g. underwriting expensest are a partial measure of the shadow cost difference between external funds and internal funds. Using data on securities issued by Compustat industrial firms over the period from 1980 through 1993. they find that high-underwriting-expence firms have: higher investment rates. larger stocks of financial working capital relatice w physical capital. lower dividend payout rates, and higher ratios of market ralue of equit! to hook value of equity. (Indeed. they find monotonic relationships for each vartable across four expense categories.) These characteristics are very similar to those of the firms identitied as financially constrained in FHP

\section{B. Investment Opportunities and $Q$}

The $Q$ model's usefulness in this literature stems from its ability to link investment to the increatse in firm value from an increment to the capital sock. B! specifying a functional form for costs of adjustment. one can solve for an investment function, relating the rate of investment to Q. A stumbling block in this approach is that the observable proxy for marginal Q. average Q. may be a poor proxy for the theoretical variable because of, inter alia. a hreakdown of efficient markets or capital-market frictions. All research in this 
literature, including the initial FHP paper, has recognized this potential problem. In particular, the $Q$ model may be a questionable framework for analysis under an asymmetricinformation alternative to the conventional perfect-capital-markets model, because market expectations may not reflect insiders' valuations of opportunities. In this case, cash flow may simply measure investment opportunities better than $Q$. Moreover, this problem may be most acute in the younger, low-dividend-payout firms considered by FHP.

One approach generalizes the basic $Q$ model by deriving a model of capital accumulation with multiple capital inputs. In the specification used by Hayashi and Inoue (1991). for example, the error term in the investment rate $-Q$ relation is a technology shock to the profit function that subsumes adjustment costs. In this interpretation, realizations of variables such as cash flow are influenced by this shock and would obtain statistically significant regression coefficients in a conventional $Q$ specification. Hayashi and Inoue attempt to reduce the problem by combining the structure of the $Q$ model and an assumed serial correlation structure of the error term. In this way, they can first-difference the model to remove the permanent component of the error term, while using lagged and/or future endogenous variables as instruments to circumvent the correlation between the temporary component and $Q$. Hayashi and Inoue still find that cash flow has significant explanatory power beyond that from $Q$ even after removing simultaneity bias; they do find somewhat larger and more precisely estimated $Q$ coefficients than those of FHP, however.

A second approach to this problem avoids finding proxies for marginal $Q$, and relies on the firm's Euler equation to model the investment decision. Absent information-related financial trictions, the usual Euler equation describing the choice of the capital stock should 
hold across adjacent periods. Alternatively, if firms face financing constraints, the standard Euler equation is misspecified, and other variables, such as proxics for internal net worth, may play a role in the investment decision. ${ }^{+}$This approach addresses two of the concerns with the $Q$ framework. "First, by not relying on the "investment function" representation, one can sidestep problems of measuring marginal $Q$. Second. by allowing the effect of net worth on investment to vary systematically, one can model directly its role in the investment process.

Gilchrist (1991), Whited (1992), Hubbard. Kashyap, and Whited (1995), and Bond and Meghir (1994) use panel data on manufacturing firms to estimatc the Euler equation. The first three studies use Compustat data for the United States. They are unable to reject the frictionless neoclassical model for firms with significant dividend payouts. The frictionless neoclassical model is easily rejected, however. for firms with low dividend payouts prior to the estimation period. These findings corroborate the cross-sectional differences noted by FHP. In addition. Whited (1992) and Hubbard. Kashyap, and Whited (1995) specify alternative models with a borrowing constraint. Whited allows the shadow cost of external finance to depend on the firm's debt-to-assets ratio and interest coverage (interest expense

\footnotetext{
+ While estimating Euler equations offers important benefits in testing the implications of neoclassical investment models with and without information-related capital-market imperfections, the approach relies on the period-by-period restriction derived from the firm's first-order conditions. This test may not pick up the effect of capital-market imperfections on decisions by firms for which the overall level of investment is constrained by internal funds but which do not appear constrained this period relative to next.

${ }^{5}$ As long as one makes the same assumptions about technology and adjustment costs, the Euler equation can be derived from the same model as the conventional $Q$ or user cost of capital models.
} 
divided by cash flow plus interest expense). In the treatment by Hubbard, Kashyap, and Whited. firms' shadow cost of funds depends on firm-specific cash flow and a measure of tightness in aggregate credit conditions (the change in the spread between the interest rates on six-month commercial paper and Treasury bills, interacted with cash flow). Both measures affect investment for the sample of firms for which the frictionless neoclassical model is rejected. and the Euler equation based on the alternative model is not rejected when both additional variables are included.

Bond and Meghir (1994) estimate Euler equations using panel data on U.K. manufacturing corporations. They reject the perfect-capital-markets model. Current investment is positively related to lagged cash flow even after controlling for output fluctuations and debt. While this role for cash flow is inconsistent with frictionless models, it is consistent with an alternative model with financing constraints. This violation of the frictionless model is most prominent for low-dividend-payout firms.

A third approach that addresses the question of whether liquidity variables are just proxics for marginal $Q$ in FHP-style regressions uses a forecasting method, as developed for time-series data by Abel and Blanchard (1986). Gilchrist and Himmelberg (1994) extend this setup to a panel-data setting. They construct investment fundamentals by specifying a VAR lorecasting framework to decompose the effect of cash flow on investment into two distinct components -- one that forecasts future protitability under perfect capital markets (analogous to $Q$ ) and a residual component that may be altributable to financial frictions. They then test whether cash tlow is an independent "fundamental" variable explaining investment. This is a test of the restricted model against the alternative that current profits have explanatory power 
beyond their ability to predict future profits. Gilchrist and Himmelbere find both that cash flow is an independent fundamental and that excess sensitivily to cash llow is a characteristic of tïms identified as constrained (e.g., by size. bond rating. commercial paper rating, or dividend payout). They also find that. for constrained firms, investment is much more responsive to cash flow than to "fundamental Q." Gilchrist and Zishrajsck (1995) extend this analysis to the quarterly firm-level data underlying the Quarterly. Finumial Reports. They show that excess sensitivity of investment to cash flow is a characteristac only of a priori constrained firms (as indicated by the absence of a bond rating or zero dividend payout).

\section{Independent Changes in Internal Funds}

Closely related research has considered ways to measure changes in firms' internal finance or net worth that are uncorrelated with investment opportunities. and then tested the impact of thesc changes on investments. Hubbard (1995. section $3 D$ ) identifies five separate lines of inquiry that have emerged in recent literature to address this point. The first relies on vartation in firms lax payments that are imperfectly correlated with hilts in investment upportunities (see Calomiris and Hubbard. 1995: and Hubbard. Kanhyap. and Whited. 1995). The second considers historical episodes of debt detlation. in which an increase in real debi hurdens weakens horrowers' capacity to finance any given set of potential investments (see Bermanke. 1983: and Calomiris and Hubbard. 1989). Third. Lamone (1993) examines investment decisions of oil firms operating in multiple (and. in particular, oil and non-oil) lines of business. He assesses effects of each cash flow shocks from the oil businesses on 
investment in the non-oil businesses. His finding of a positive effect of oil-related cash flow on non-oil related investment, holding constant investment opportunities, lends support to an independent channel for cash flow. Fourth, Froot and Stein (1991) and Tevlin (1994) find that revaluations of foreign multinational firms' internal resources owing to exchange rate fluctuations affects their cost of funds for acquisitions in the United States.

Finally, Fazzari and Petersen (1993) add changes in working capital to the basic FHP specification. Their intuition is as follows. On the one hand, if effects of cash flow on investment represent omitted shifts in investment demand (i.e., sales and profits), then changes in working capital, which are themselves positively correlated with sales and profits, should have a positive coefficient in the investment regression. On the other hand, suppose that costs of adjusting the stock of working capital are lower than costs of adjusting the stock of fixed capital. Then, financially constrained firms (for which the costs of external finance are high) may draw down working capital to mitigate temporarily the effect of an adverse shock to cash flow on investment. In this case. investment in working capital should have a negative coefficient when included in the FHP regression. Using the FHP panel data, Fazzari and Petersen find that the estimated working-capital-investment coefficient is indeed negative for the low-payout firms, casting doubt on the notion that estimated effect of cash flow on investment largely reflects omitted shifts in investment demand. In a related inquiry, Calomiris. Himmelberg, and Wachtel (1995) use bond ratings or access to bond and commercial paper markets to sort firms according to financing costs. They find that firms with no ratings or with lower credit quality ratings -- which tend to be smaller firms with lower dividend payout .- hold larger stocks of liquid assets and display much more cash flow 
sensitivity of investment in working capital. These findings suggest a "buffer stock" role for liquid assets for financially constrained firms.

$\mathrm{KZ}$ do not consider the support these diverse tests provide for the basic FHP findings.

\section{Links Between Cash Flow and Investment in Non-Value-Maximizing Firms}

The empirical tests discussed thus far treat the effect of cash flow on investment as representing a higher shadow cost of external funds. Alternatively. Jensen (1986) has emphasized a potential connection between changes in internal funds and corporate expenditures (including capital spending) holding constant investment opportunities, arising from management's use of internal funds for non-value-maximizing projects. He argues that the availability of "free cash flow" -- the difference between cash receipts and the sum of cash disbursements and spending on profitable investment opportunities -- raises corporate investment independent of underlying signals about expected future profitability. The argument is difficult to test directly owing to the unobservability of free cash flow. In the cases for which the theory is correct, for example. we could not use reported data on investment to construct the measure.

Hubbard. Kashyap, and Whited (1995) offer an indirect lest of the free cash flow model's prediction for capital spending. Using a number of criteria. they classify 39 four-digit S.I.C. manufacturing industries as "mature." with high average profitability. The firms in these industries were large relative to other firms in the sample. The authors separated the low-dividend-payout firms according to whether they fell in the mature industries. The estimates do not support the idea that mature. low-payout firms (those emphasized by the free 
cash flow approach) account for the rejection of the neoclassical model. Indeed, for that subsample, estimated coefficients are plausible and in line with the estimates for the other sample splits; moreover, the model's orthogonality restrictions cannot be rejected. This evidence does not imply that agency-cost considerations are unimportant. Rather, the findings suggest that the free cash flow story does not appear to explain the effect of internal funds on investment in plant and equipment.

\section{THE KAPLAN-ZINGALES CLASSIFICATION APPROACH}

Kaplan and Zingales introduce a new approach for classifying firms into constrained and unconstrained categories. They integrate firm financial data with "public news" and "management's discussion of liquidity that describes the firm's future needs for funds" (page 2) to sort firms into one of five groups: Not Financially Constrained (NFC), Likely Not Financially Constrained ( $L N F C$ ), Possibly Financially Constrained $(P F C$ ), Likely Financially Constrained ( $L F C$ ), and Financially Constrained $(F C) . \mathrm{KZ}$ describe their most clear-cut groups, NFC and $F C$ firms, as follows (pages 10 and 11 ):

We place a firm-year in the NFC group if the firm initiated or increased cash dividends, repurchased stock, or explicitly indicated in its annual report that the firm had more liquidity than it would need for investment in the forseeable future. We also were more likely to label a firm-year $N F C$ if the firm had a large cash position (relative to investment) or if the firm's lenders did not restrict the firm from making large dividend payments (relative to investment). NFC firm-years, therefore tend to include financially healthy companies with low debt and high cash flow. In NFC firm-years, therefore, we find no evidence that these firms could not have invested appreciably more if their managers had so chosen. [Emphasis in the original.]

The last group includes all firm-years in which firms are undoubtedly financially 
constrained $(F C)$. In these firm-years, these companies are in siolation of debt covenants, have been cut out of their usual source of credit. are renegotiating debt payments. or declare that they are forced to reduce insesments beciuse of liquidity problems.

KZ apply this classification scheme to the FHP sample of low-dividend firms and conclude that the vast majority of these firms do not face financing constratuls most of the time. Furthermore. $\mathrm{KZ}$ find that the firms they classify as mont likely wo he constrained demonstrate a smaller sensitivity of investment to cash flow than the firms chawhich as not financially construmed. From these results. KZ conclude that the findings reported in FHP do not indicale the presence of financing constraints."

We disagree with these conclusions. In this section. We dextribe serious shortcomings in the $\mathrm{KZ}$ method. Our criticism of their approach is argathized mo ilie parts, addressing problems raised by the: (1) complex and subjective criteria they use for grouping firms, (2) reliance un managerial statements about liquidity. (3) problematk uperational definition of what it means for a firm to be financially constrained. th apprombh wed to distinguish the

$K Z$ define their other classifications as follows quotes from pages 10 and 11 ):

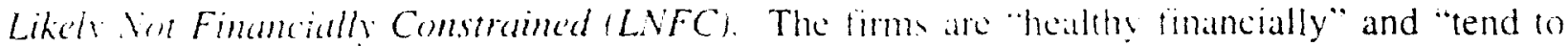
have veahle cash reserves. unused lines of eredit. and healthy interen coverage. LNFC firm-years ate distinguished from NFC fïm-years by an ibsence of an explicil statement of excess liquidity and by the magnitude of the measures of liquidity."

Passibh Financially Comstrained (PFC). "In PFC firm-years. fims do not report any clear signs of linancial constraints, but they do not look particalarly liquid either."

Likels Fincuncislls Constrained $(L F C)$. "This group includes firms that mention having difficulties in obtaining financing. ... Generally, these companies are prevented from paying dividends and have little or no cash avalable. Companies that cut dividends also are more likely wh hall in this cattegory." 
degree of financing constraints across firms, and (5) absence of heterogeneity in the sample firms along the dimensions that $\mathrm{KZ}$ emphasize. In section $\mathrm{V}$, we discuss some econometric problems with the $\mathrm{KZ}$ results.

\section{A. Complexity and Subjectivity in the $K Z$ Classification Approach}

The conclusions we reached in FHP were based on a relatively small data sample (of which $\mathrm{KZ}$ examine only a subset). Moreover, there were many econometric and modeling isstes that we did not address in the original FHP paper. As we discussed in section III above. however. subsequent research has replicated and extended the FHP findings in many ways. The FHP approach was easily reproducible, and hence could be extended by other rescarchers to new data and new econometric models. It is the results of this extensive recirch. Father than only the specific findings in FHP, that now establishes what we believe is a very strong case for the presence of financing constraints on firm behavior.

A similar examination of the $\mathrm{KZ}$ results would be difficult. The quotes from $\mathrm{KZ}$ preselled above show that $\mathrm{KZ}$ usc multiple criteria in a complex way to sort the FHP firms into their tive groups. They do not discuss the weights they put on different criteria. Rather, statements that they "were more likely to label a firm-year as ..." indicate the need for considerable subjective judgment in their classification approach. It therefore appears to us that it would be very difficult, if not impossible, for future researchers to use the $\mathrm{KZ}$ approach in future studies on other data or with different econometric approaches. Hence one could always debate whether future altempts to extend KZ's work had grouped firms in accordance with the $\mathrm{KZ}$ strategy. 


\section{B. Reliance on Managers' Statements}

In classifying firms. KZ use managers statements about the liquidity of their firms and the ability of their firms to obtain outside linancing. We quevem the credibility of such statements. Managers surely have incentives to paint an optimmste picture. Statements about problems in access to financial markets are likely to be self-fullilling. It is certainly bad news to potential shareholders and other outside suppliers of linance if firms admit that they must sicrifice desirable investment projects because of their inathility to obtain external finance at reasonable terms.

To justify their use of managerial statements. KZ rely hamlly on Regulation S-K. which they state requires managers to discuss firms liquidity and captlal resources. They protide yuotes from the regulation that ask firms to identily reasoms why their liquidity may be increasing or decreasing and to report their commiments fur fume capital expenditures. $\mathrm{KZ}$ comclude that Regulation S-K explicilly requires firms to dixcluse whether or not they are having difficulty financing their investments" (page 91 . It is mo whous. however, that the instructions in Regulation S-K are designed to force a firm 10 reseal whether or not it is

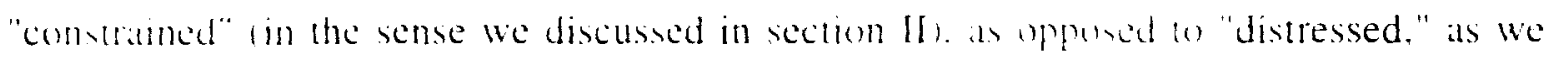
discuss in the subsection IV.D below. Second. the insmetum are not precise. and firms are

The discussion of long-term liquidity and long-kem capial resources in Regulation $S-K$ addienses commitments, not desired spending per se. The disclosures are designed to focus more an liquidity problems related to incipient distress rather than on information-related financme costs. An additional problem is that honterm liquidity and capital resources were not comparatble from registrant to registrant until the issuance of SFAS 95 by the Financial Accounting Standards Board. which mandates that the tatement of changes in financial postion he replaced by a statement of eash flows as patt of a full set of financial statements and whoth is required for anmual limancsal stalements for fiscal sears ending after July 15. 
likely to have different interpretations of what is requested. Finally, as noted above, we are skeptical of any statements in annual reports about the absence of financing constraints because it is likely to be bad news to shareholders if firms state that they must turn down profitable projects because of the need to pay a high premium for external funds. ${ }^{8} \mathrm{KZ}$ recognize this point. writing that "any management reluctance to report negative information should bias our results against finding financially constrained companies" (page 12).

An example of the difficulty of interpreting managerial statements about the presence or lack of financing constraints is instructive. Chrysler recently claimed that it requires a several billion dollar cash hoard to survive temporary negative cash flows during recessionary periods. The firm claims to be following the successful strategy pursued by Toyota. Are Chryster's and Toyota's managers correct in saying that their firms face serious financing constramts? Many economists would answer no. It is plausible that the managers of these firms simply do not want to turn over the cash to shareholders and face the scrutiny of capital markets. Of course. managers would never admit to following such a policy. We doubt the usefulness of relying in large part on the statements of managers, especially public statements to their shareholders. to determine whether firms face financing constraints. ${ }^{9}$

1988. These observations are based in part on the interpretative analysis of Regulation $S-K$ in Murrat. Decker. and Dittmar (1993).

"For example, KZ begin their paper with a quote from the 1982 annual report of Hewlett-Packard, which includes the statement that the company's self-financing concept has not been a constraint on the company's growth. Because the management had clearly decided to fund the firm's investments internally. it is unlikely that management's annual report would sily anything different.

"We also question whether managers" statements can credibly distinguish relative differences in the extent of constraints (as opposed to the absolute level of constraints). As discussed helow. growing healthy firms that exhaust internal financial sources may be the 


\section{Definition of Financing Constraints}

Throughout their paper, KZ's operational definition of what it means for a firm to be financially constrained is whether the firm "could have invested appreciably more if their managers had so chosen." (See. for example, the italicized statement in their description of both their NFC and LNFC categories on page 10.) They use the presence of cash stocks or unused lines of credit to indicate that lack of finance does not pose a barrier to greater investment. With this operational definition, $\mathrm{KZ}$ conclude that 85 percent of the firm-years in the FHP low-dividend sample are either not or likely not financially constrained.

We do not accept the operational definition cmplosed by $\mathrm{KZ}$. and we disagree with their conclusion that financing constraints are almost completely absent from the FHP lowdividend sample. The $\mathrm{KZ}$ definition requires firms to be incredibly short-sighted, which we do not believe. Suppose a firm must pay a substamtial promium for external funds. For reasons discussed in a number of recent papers (Fazzari and Petersen. 1993; Carpenter, Fazzari. and Petersen, 1994: Calomiris. Himmelberg. and Wachtel. 1995: and Calomiris and Himmelberg. 1995), it is costly for firms to adjust investment expenditures to the fluctuations in internal finance that frequently buffet firms in the economy. Rational firms operating in imperfect capital markets will therefore partially protect themselves by building buffer stocks of cash or maintaining unused debt capacity. Such firms may be able to invest more at the margin at any point in time. but the firm is nonetheless financially constrained. This is a sharp point of disagreement between $\mathrm{KZ}$ 's view of financing constraints and our own: They

most constrained firms. But the mamagers of such firms have no need to reveal insuffictent licpuidity. 
emphasize a static and, in our view, very limited concept of financial constraints (what they call "contemporaneous" constraints) while we (and most other researchers) take a longer-run, more dynamic perspective.

On a related point, $\mathrm{KZ}$ fail to recognize that firms have substantial other uses for their internal finance besides fixed capital investment. They interpret the fact that the median "net cash flow" ratio (cash flow less investment divided by capital) is 11 percent for NFC firms as evidence that these firms are not constrained. They state (page 13) that this statistic "suggests that NFC firms could have increased their investment without tapping external sources of capital" and should therefore not be classified as financially constrained. This conclusion is unwarranted. As firms grow, they expand not only fixed capital, but also the stock of working capital. Indeed, working capital constitutes a major portion of firms' assets, and, because of constrained firms' need for liquid assets discussed above, working capital is likely to be especially important for firms facing financing constraints. In the same FHP sample that KZ study, Fazzari and Petersen (1993) show that median working capital investment is about 65 percent of fixed capital investment (both variables were scaled by the stock of fixed capital). Using this figure to estimate median working capital investment for the $\mathrm{KZ}$ subgroups, median total investment in fixed and working capital more than exhausts all of median cash flow for all of the $\mathrm{KZ}$ categories, consistent with the view that these firms face financing constraints. ${ }^{10}$

${ }^{10}$ For example, a firm could have cash flow equal to twice the value of fixed investment and still be precluded from undertaking new fixed capital projects because external finance is excessively costly and the marginal cost of reducing working capital investment is too high. 


\section{The Degree of Financial Constraints and the Sensitivity of Investment to Cash Flow}

To divide the $49 \mathrm{FHP}$ firms into five subgroups, $\mathrm{KZ}$ make rather fine distinctions in the degree of financing constraints. This task is extremely difficult, and such a detailed classification has not been altempted in previous research. We do not believe $\mathrm{KZ}$ are successful in this task. in large part because of difficulties in devising operational criteria for what it means to be more or less financially constrained. Rather, we argue that as one goes from the NFC (not financially constrained) category to FC (financially constrained) category it is the degree of financial distress that increases rather than the degree of financial constraints. As a consequence, there is no reason to expect a systematic pattern in the censitivity of investment to cash flow across the $\mathrm{KZ}$ categories.

It is difficult to distinguish the degree of financing constraints by observing "cash reserves" and "leverage," two of KZ's main classification criteria. They maintain that large cash reserves and low debt levels indicate that a firm is less financially constrained (or, as they frequently argue. not constrained at all). In practice, however, this need not be the case. Firms may have low debt, for example, because they cannot convince lenders to provide them with credit perhaps due to lack of collateral. Low collateral value of assets is typical of firms in high-lech industries. which also tend to have low debt-equity ratios (see, e.g., Himmelberg and Petersen. 1994): yet one would not want to argue that high-tech companies do not face linancing constraints.

Linking large cash stocks to the absence of financing constraints is also unwarranted. As discussed above, in the presence of adjustment costs, firms will choose to smooth clatively illiquid fixed capital investment by maintaining buffer stocks of cash. While it may 
be momentarily feasible for a firm to invest more in the current period by consuming much or all of its cash. it may rationally choose to preserve cash for self-financing in periods when the now of internal funds is low. perhaps even negative. Other things equal, the more precarious is a firm 's access to external finance. the greater are its incentives to build up buffer stocks of casth to guard against inevitable future downturns in internal finance. Indeed, one wonders why firms hold large stocks of cash if. as $\mathrm{KZ}$ seem to suggest, they can readily replace shortfalls in the flow of internal funds with external finance.

If the $\mathrm{KZ}$ classification does not identify financial constraints, what does it accomplish? We believe that as one goes from NFC (not financially constrained) to $F C$ (financially constrained) firm-years it is the degree of financial distress that increases. In the passages quoted above, $\mathrm{KZ}$ themselves describe their classification scheme in this way, cmphasizing the "financial health" of NFC firm and "liquidity problems" of $F C$ firms. The summary statistics presented by $\mathrm{KZ}$ in Table 3 illustrate this outcome in their classification of the FHP firms. The mean cash flow-capital ratio for the $F C$ firm-years is -0.047 , and the mean mterest coverage ratio is a low 1.650. At the other end of the classification scheme, the $V F C$ observations come from years when firms are doing well. Here, the median cash flowcilpital ratio is 0.506 . Interest coverage in the $N F C$ firm-years, is also high, which is not at all surprising. given the high level of cash flow. We do not dispute the fact that these NFC observations represent firms at times when they are financially healthy and performing well. This does not imply. however. that NFC fïrm-years are "not financially constrained."

Financially healthy firms can fund more investment from internal sources, but it does not follow that they are less financially constrained. The investment of NFC firms is likely to 
exhibil high sensitivity to cash flow. possibly higher than that for financially distressed LFC or FC firms. Successful. fast-growing firms are the most likely th have the best new profit opportumities and their demand for finance is also greater. The summary statistics in Table 3 of $\mathrm{KZ}$, how that both the sales and capital of their NFC tirms nom more quickly than the other chanes.) As a result. the investment of financially hadthy firm may be very sensitive to their llow of internal finance. (As we noted above. the thlintle reported by $\mathrm{KZ}$ are consistent with internal funds being exhausted for median tirm-salls th the NFC category.) The growth and success of firms like those in KZ'S NFC caterom may make their balance sheets and income statements look quite healthy. hut thw and :-wowh also pushes them to the margin at which financing constraints bind."

At the other end of the $\mathrm{KZ}$ spectrum, we agree that the fimancially distressed firms in the $F C$ and $L F C$ categories are constrained in their acees 10 men cxtemal finance. but their invesment may not be highly sensitive to cash flow. Recall that the $\mathrm{KZ}$ criteria for $F C$ firms includes violations of debe covenants and renegotiation of deht payments. When firms are under such financial distress, their creditors are likely w force them to use cash flow to meet inceres payments and to improve the liquidity of heir halance hect. In this case. firms are

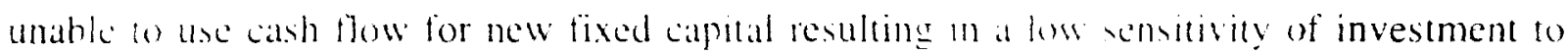
ansh hmo:

Indeed. Calomiris. Himmelberg. and Wached (1995) lind that less mature firms with no bond rating grow faster and appear more financially "healthy" than more mature rated firms. One would not typically think of the nom-rated firms an being less constrained, however.

KZ reognize this possibility. They defend their approach against this criticism (page 261. but their arguments are not convincing. For example. they argue that firms increase rather than repay debt in the years they classify as PFC. LFC. and FC. This observation. howeres. mats be due to creditors permining illiquid. hu last-growing firms to rebuild 


\section{E. The KZ Classification and Heterogeneity}

One of $\mathrm{KZ}$ 's most striking findings is how few observations fall into their $F C$ and LFC groups. After their in-depth examination of each firm-year in the FHP sample, they could classify only 19 of 719 observations (2.6 percent) as $F C$ (financially constrained) and another 34 observations ( 4.7 percent) as $L F C$ (likely financially constrained). We are not surprised by this outcome. By choosing dividend payout as the indicator of financing constraints in FHP. we recognized that one reason a firm may pay low dividends is because it experienced financial distress, in many cases earning negative cash flow. Given our objectives in FHP. however, we wanted to focus on firms with profitable growth opportunities that paid low dividends to fund new investment. We attempted to exclude financially distressed lirms by design. "Accordingly, we expect few of our sample observations to fall in the $F C$ and $L F C$ categories.

Most recent studies of financing constraints, following FHP, have attempted to exploit heterogeneity among firms financial circumstances to identify the importance of the constraints. Firm heterogeneity is also critical in the $\mathrm{KZ}$ study. However, the paucity of observations in the $F C$ and $L F C$ groups causes serious doubt about whether $\mathrm{KZ}$ have any useful hetcrogeneity remaining in their sample along the dimensions they emphasize. Indeed,

liquidity. Because these firms need additional liquidity, all sources of funds, including cash flow. may be directed to liquid assets rather than fixed investment.

"We found that limiting the sample to those Value Line firms that had positive real sales growth over the entire sample period effectively selected low-payout firms that were tinancially healthy. 
one might wonder how they can run regressions for their constramed groups when so few observations fall into the constrained categories. The appendix lable in $\mathrm{KZ}$ gives the detailed classification of each firm-year and shows how the firms were grouped for the empirical tests. To obtain a meaningful sample size for regressions, firms were put in the $F C$ category (the most distressed of their regression categories) if they had just a vingle year (out of 15 sample yearsi with an $F C$ or $L F C$ rating. In the $F C$ regression sample. $1+$ if the 22 firms had an $F C$ or LFC rating only one or two times: that is. less than 1.3 percent of the time. Of the remaining cight firms. six had $F C$ or $L F C$ ratings in fun thee ur find of the 15 sample vears. No firm had FC or $L F C$ ratings for more than to percent of the ample years.

This outcome leads to serious questions itbout how to interpret the $\mathrm{KZ}$ regression results. Even if one accepts (which we do not) that the $k Z$ classilicalions relate to the severty of tinancing constraints, the sample that $\mathrm{KZ}$ uc has vithally no information from firm-lears in their constrained categories. ${ }^{14}$

\section{ECONOMETRIC PROBLEMS}

$\mathrm{KZ}$ emphasize throughout their paper that the firms they classify as "not financially constramed" exhibit a significuntly larger ensitivity of investment to cash flow than those

On page 26. $\mathrm{KZ}$ write that it is "unreasonable to describe the likely constrained firms as discessed over the entire sample period." We agree with this conclusion, but find it puzzling in this context because. given the $\mathrm{KZ}$ definnion of $F C$ and $L F C$ firm-years, if firms are not financially distressed. they should not he clasilfiel in the $F C$ sample for regression purposs. 
firms classified as "financially constrained." We have explained why we disagree with KZ's assertion that their NFC firms are not financially constrained and why we believe there is little evidence that $\mathrm{KZ}$ classified the $49 \mathrm{FHP}$ firms in a way that measures differences in the degree of financing constraints. We have also explained why their FC firms may have a lower sensitivity of investment to cash flow than their NFC firms in the presence of financing constraints. This section explores further explanations for the pattern of KZ's regression results: measurement error and censored regression bias.

\section{A. Measurement Problems}

$\mathrm{KZ}$ follow the FHP approach of using $Q$ to control for investment opportunities. The $Q$ variable must be constructed. KZ's definition of $Q$ (the market value of assets divided by the book value of assets) has two problems. First, they use total assets rather than fixed capital. and. second. they use book values rather than replacement costs. Both measurement problems could introduce biases that might explain part of the differences they find across investment regressions for different classes of firms.

The $Q$ theory implies that fixed capital investment is determined by the ratio of market Value of capital to the replacement cost of capital. By using total assets rather than capital, the $Q$ ratio relevant tor fixed investment may be mismeasured. ${ }^{15}$ The potential significance of this problem is apparent from statistics presented in Fazzari and Petersen (1993) showing that median working capital. for the same sample of firms that $\mathrm{KZ}$ analyze, was about 75 percent

${ }^{15}$ In FHP, we addressed this problem by subtracting an estimate of the market value of inventories from the numerator of $Q$. 
of the fixed capital stock. The assets of these firms consist of more than just fixed capital. Perhaps more serious is the fact that the denominators of Q. the investment-capital ratio. and the cash flow-capital ratio used by $\mathrm{KZ}$ are measured in hook rather than market values. The sample period (1970-84) contains the century's highes intiation rates for the Lnited States. Book values are based on the histortial cont of anseth. These values will deviate from the theoretically correct concept of replacement cosm in an intlationary enviromment. Moreover, the extent of the measurement problem will depend on cumulative historical inflation over the asset lives of the firm capial. The meanurement error is likely to vary over this sample period because previous inflation wals moket in the early part of the sample. but quite substantial by the end of the sample. This prothlem could introduce trends in all of the $\mathrm{KZ}$ regression variables that would not be captured hy tim fixed effects."

The extent of these problems maly differ systematically acron firm groupings; hence measurement errors may be in part responsible for differences in the estmated cash flow coefficients $\mathrm{KZ}$ find between FC and NFC firms. For example. the meanurement biases resulting from using book values in an inflationary environment would likely affect fastgrowing tïms with a more recent vintage of capital differenty from 4 low-growing firms. Studies of this kind must. therefore. attempt to correct for meatsurement problems when possible

16 FHP and subsequent researchers in this arcat have used variants of an algorithm developed by Salinger and Summers (1983) to build up an estimale of the replacement cost of the capital wock from year-by-year firm investment data and aggegate capital goods price lata. Another probtem with book value of assets is that they are detemined using possibly arbitrary accounting depreciation rules. The Salinger-Stummers algorithm uses accounting data to estimate economic depreciation. 


\section{B. C'ensored Regression Bias}

The results in the initial FHP study, and probably many suhecquent studies, may underestimate the cash flow coefficients for financially constrained tims. This is because. while cash llow can be negative, gross fixed investment as it is typkially measured in available diatia sets) cannot be less than zero. In fact. to make production technically feasible. firms probably require some positive level of gross investment to replace obsolete or inoperable equipment. Even if firms are financially constraned. imserment may not decline with cash tlow once investment has fallen to a minimum lesel necessary to carry on production. In the presence of very low or negative cash flow cualisations. a regression of investment on cash flow maly result in a downward hias in the estimatted cash flow coefficient compared to what one would obtain for firms with normal ferels of cath flow.

In the FHP data that $\mathrm{KZ}$ study, there are observations of negative cash flow, along with positive, hut often very small observations of calsh flow. This litc is evident from the statistics in KZ's Table 3. Not surprisingly. these negative and small prositive cash flow observations are concentrated almost exclusively in the PFC: $L F C$. and $F C$ (possibly, likely. and definitely constrained) categories. In these cattegrories, the catsh flow-capital ratios, at the loh percenter are $-10.125,-0.126$ and -0.436 . respectively. In fact. for the $F C$ category, the mean value of the eash flow ratio is -0.047 . In contrast. the calsh flow-capital ratio, at the 10th percentile for their NFC observations. is a healthy 0.209.

These findings are consistent with our conclusion that the $K Z$ classification system places a large number of financially distressed obserwations into their $L F C$ and $F C$ categories. Thus, their classification system has inadvertenty concentrated the censored regression 
problem in their so-called financially constrained category. We believe that this fact may explain much of the differential in the cash flow coefficients across their categories of firms.

There is additional evidence in the $\mathrm{KZ}$ summary statistics to support this conclusion. In Table 3. the median investment-capital ratio for $F C$ firms is 0.243 , a very high value. How can the median investment ratio for financially constrained firms be so high when median cash tlow is near zero? A check of the inventory growth numbers sheds some light on this question. The median inventory growth rate for $F C$ firms is -6.4 percent, which is very different from the 20 percent growth rate of inventory investment for the $N F C$ firms. As we have already argued. inventory investment is a major use of cash flow for rapidly growing companies, and all of these firms are relatively rapidly growing (over the full sample period). Firms can readily divest assets such as inventories, however, to offset a temporary shortfall of internal funds. This divestiture generates cash that allows the firm to maintain investment levels in other activities in the short run.

Why would firms behave in such a fashion? The likely explanation is that firms will seck to smooth investment in activities with high adjustment costs (see, e.g., Fazzari and Petersen. 1993: Himmelberg and Petersen, 1994: Carpenter, Fazzari, and Petersen, 1994; and Calomiris. Himmelberg, and Wachtel. 1995). ${ }^{17}$ Combining financing constraints and investment smoothing leads to the prediction that optimizing firms will allow reversible assets with low adjustment costs to bear the brunt of negative shocks to cash flow in the short run.

is Several papers outside of the financing constraints literature conclude that physical investment has a high adjustment cost relative to inventory investment; see, for example, Zarnowitz (1992). 
These assets include working capital, and more specifically, inventories. Firms frequently report negative inventory investment, which allows the firm to buffer its investment in physical capital. This phenomenon will accentuate the censored regression problem for fixed investment noted above, as financially constrained firms can maintain fixed investment for some time even when cash flow is low or negative. Relatively low cash flow coefficients for financially distressed firms (the kind that $\mathrm{KZ}$ include in their $F C$ and $P F C$ groups) are, therefore, consistent with optimal behavior of firms facing financing constraints.

\section{CONCLUSION AND A POSITIVE NOTE}

Kaplan and Zingales (1995) offer a number of criticisms of Fazzari, Hubbard, and Petersen (1988) and, by extension, they criticize much of the ensuing empirical literature that emphasizes cross-sectional tests for the presence of financing constraints on fixed investment. This reply identifies three major flaws in the $\mathrm{KZ}$ analysis. First, the questions $\mathrm{KZ}$ raise about how estimated cash flow coefficients should be interpreted have already been considered extensively and rigorously in the literature (most of which the $\mathrm{KZ}$ paper does not address). The conclusions reached in this research are broadly similar to those of the FHP study. Second, the classification scheme employed by $\mathrm{KZ}$ suffers from a variety of problems: it is complex and judgmental; it relies on statements by managers that may not reflect economic realities; it employs an unrealistic definition of financing constraints, and it does not identify fine differences in the degree of financial constraints, as $\mathrm{KZ}$ claim, but rather it emphasizes financial distress. Third, the results obtained by $\mathrm{KZ}$ may reflect econometric problems, some 
of which are predicted by recent research on financing constraints. We conclude that the $\mathrm{KZ}$ findings are consistent with the presence of financing constraints and do not contradict the interpretations given by FHP and subsequent research.

In spite of these criticisms, we agree with $\mathrm{KZ}$ that more research is needed to isolate the sources of capital-market imperfections that affect firm decisions. KZ suggest "managerial risk aversion" as an alternative explanation for a correlation between investment and liquidity. ${ }^{18}$ This suggestion is intriguing and could be fruitfully explored in future work. "Conservative" managers might hold larger stocks of cash and tie investment spending more closely to internal funds. Careful consideration of this idea requires a study significantly different from the present exercise. First, one would need to specify a model in which firms with risk-averse managers and firms with risk-neutral managers coexist. (Such a model presumably incorporates an informational friction or a friction in markets for risky debt to forestall takeovers of firms with risk-averse managers.) Second, empirical tests require a broader set of firms with variation across firms in managerial risk aversion (e.g., to follow the "Depression baby" characterization in $\mathrm{KZ}$, one could consider ages of senior managers).

In their conclusion, $\mathrm{KZ}$ note that "a great deal can be learned through direct observation." Of course, we agree. However, the significance of the financing constraints literature that Kaplan and Zingales criticize, in our view, necessarily traces to its use of theoretical insights as a lens through which one can make sense of "direct observation."

18 Whether their characterization of "risk aversion" is a preference-induced departure from risk neutrality is not clear. Previous researchers (e.g., Greenwald, Stiglitz, and Weiss, 1993); and Grossman and Vila, 1992) have described ways in which capital-market imperfections induce managers to behave in risk-averse ways. 


\section{REFERENCES}

Abel. Andrew B.. and Olivier J. Blanchard. "The Present Value of Profits and Cyclical Movements in Investment." Econometrica 54 (March 1986): 249-273.

Bernanke. Ben. "Nonmonetary Effects of the Financial Crisis in the Propagation of the Great Depression." American Economic Reliew 73 (June 1983): 257-276.

Bernanke. Ben. Mark Gertler. and Simon Gilchrist. "The Financial Accelerator and the Flight to Quality." Review of Economic and Statistics, forthcoming, 1995.

Bond. Stephen. and Costas Meghir. "Dynamic Investment Models and the Firm's Financial Policy." Review of Economic Studies 61 (April 1994): 197-222.

Calomiris. Charles W.. and Charles P. Himmelberg. "Investment Banking Costs as a Measure of the Cost of Access to External Finance." Mimeograph, University of Illinois, April 1995.

Calomiris. Charles W., Charles P. Himmelberg, and Paul Wachtel. "Commercial Paper and

Corporate Finance: A Microeconomic Perspective." Carnegie-Rochester Conference Series on Public Policy, forthcoming, 1995.

Calomiris. Charles W.. and R. Glenn Hubbard. "Internal Finance and Investment: Evidence from the Undistributed Profits Tax of 1936-1937." Journal of Business 68 (October $1995): 4+3-482$.

Calomiris. Charles W.. and R. Glenn Hubbard. "Price Flexibility, Credit Availability, and Economic Fluctuations: Evidence from the United States, 1894-1909." Quarterly Journal of Economics 104 (August 1989): $429-452$.

Carpenter. Robert E.. Steven M. Fazzari. and Bruce C. Petersen. "Inventory Investment, Internal-Finance Fluctuations, and the Business Cycle." Brookings Papers on Economic Activity (1994:2): 75-138.

Fazzari. Steven M.. R. Glenn Hubbard. and Bruce C. Petersen. "Financing Constraints and Corporate Investment." Brookings Papers on Economic Activity (1988:1): 141-195. 
Fazzari. Steven M. and Bruce C. Petersen. "Working Capital and Fixed Investment: New Evidence on Finance Constraints." RAND Joumal of Ecomomics 24 (Autumn 1993): 328342.

Froot. Kenneth. and Jeremy Stein. "Exchange Rates and Forcign Dired Investment: An Imperfect Capital Markets Approach." Quarterly Journal of Economics 106 (November 1991): $1191-1217$.

Gilchrist. Simon. "An Empirical Analysis of Corporate Investment and Financing Hierarchies Using Firm-Level Panel Data." Mimeograph, Board of Governots of the Federal Reserve System. November 1991.

Gilchrist. Simon, and Charles P. Himmelberg. "Evidence on the Role of Cash Flow in Reduced-Form Investment Equations." Mimeograph. View York I niversity. December 1994

Gilchrist. Simon. and Egon Zakrajcek. "Investment and the Present Value of Profits: An Analysis Using Firm-Level QFR Data." Mincograph. Bosion L Mucersity. 1995.

Greenwald. Bruce C.. and Joseph E. Stigliz. "Financial Market Imperfections and Business Cycles." Quaterly Joumal of Economics 108 (February 1903: 77-114.

Gross. David. "The Investment and Financing Decisions of Liquidity-Constrained Firms." Mimeograph. MIT. 1994.

Grossman. Sanford J.. and Jean Luc Vilat. "Optimal Dýnamic Trading with Leverage Constrants." Jommal of Financial and Quantitative Budlysis (Jume 1992): 151-168.

Hayashi. Fumio, "Tobin's Marginal q and Average $Q$ : A Veoclasicial Interpretation." Ecrmmetrica 50 (January 1982): $213-224$.

Hayashi. Fumio, and Tohru Inoue. "The Relation Between Firm Growth and q With Multiple Capilal Goods: Theory and Evidence from Pancl Data on Japanese Firms." Econometrica 59 (Maly 1991): $731-753$.

Himmelbere. Charles P. "A Dynanic Analysis of Dividend and Investment Behavior Under Borrowing Constraints." Mimeograph. New York University. 1991.

Himmelberg. Charles P.. and Bruce C. Pelersen. "R\&D and Internal Finance: A Panel Study of Small Firms in High-Tech Industries." Revion of licomemics and Statistics 76 (February 1994): $38-51$. 
Hoshi, Takeo. Anil K. Kashyap, and David Scharfstein. "Corporate Structure, Liquidity, and Investment: Evidence from Japanese Panel Data." Quarterly Journal of Economics 106 (February 1991): 33-60.

Hubbard. R. Glenn. "Capital-Market Imperfections and Investment." Mimeograph, Columbia University. December 1995.

Hubbard. R. Glenn, and Anil K. Kashyap. "Internal Net Worth and the Investment Process: An Application to U.S. Agriculture." Journal of Political Economy 100 (June 1992): 506534.

Hubbard. R. Glenn. Anil K. Kashyap, and Toni M. Whited. "Internal Finance and Firm Investment." Journal of Money, Credit, and Banking 27 (August 1995).

Jensen. Michael C. "Agency Costs of Free Cash Flow, Corporate Finance, and Takeovers." American Economic Reliew 76 (May 1986): 323-329.

Kaplan. Steven . .. and Luigi Zingales. "Do Financing Constraints Explain Why Investment Is Correlated With Cash Flow?" Working Paper No. 5267, National Bureau of Economic Research. September 1995.

Lamont, Owen A. "Cash Flow and Investment: Evidence from Internal Capital Markets." Mimeograph. MIT, August 1993.

Murray. Ronald J., William E. Decker. Jr., and Nelson W. Dittmar, Jr. The Coopers and Librand SEC Manual. sixth edition. Englewood Cliffs, New Jersey: Prentice Hall, 1993.

Salinger. Michael A., and Lawrence H. Summers. "Tax Reform and Corporate Investment: A Microeconomic Simulation Study." In Behavioral Simulation Methods in Tax Policy Analists. edited by Martin Feldstein. Chicago: University of Chicago Press, 1983. 247281.

Schaller. Huntley. "Asymmetric Information, Liquidity Constraints, and Canadian Investment." Canadian Journal of Economics 26 (August 1993): 552-574.

Schiantarclli. Fabio. "Financial Constraints and Investment: A Critical Review." Mimcograph. Boston College. May 1995.

Tewlin. Stacey. "International Acquisitions. Exchange Rates, and Informational Asymmetries." Mimeograph. MIT. November 1994. 
Whited, Toni M. "Debt, Liquidity Constraints, and Corporate Investment: Evidence from Panel Data." Journal of Finance 47 (December 1992): 1425-1460.

Zarnowitz, Victor. Business Cycles: Theory, History, Indicators, and Forecasting. Chicago: University of Chicago Press, 1992. 